\title{
Internet-Based ICT Usage By South African SMEs: The Barriers Faced By SMEs
}

Michael C. Cant, University of South Africa (UNISA), South Africa

Johannes A. Wiid, University of South Africa (UNISA), South Africa

Yu-Ting Hung, University of South Africa (UNISA), South Africa

\begin{abstract}
Previous research estimates that 8 out of 10 small and medium enterprises (SMEs) do not operate for more three years (Mason 2015). According to OECD ([sa]), the major problems encountered by SMEs relate to financing and regulatory burdens. However, with information technology, SMEs are able to narrow the information gap, which leads to improved strategies and decision making (OECD [sa]). In today's competitive world, information communication technology (ICT) is recognized as a crucial success factor for SMEs. ICT refers to the accessing and communication of information using various technologies such as the internet, wireless networks and cellphones (TechTerms 2010). This research study investigates SMEs' perception of the barriers in adopting ICT in the South African context. The objective of this paper is to determine ICT adoption and the perceived barriers associated with it among South African SMEs. A review of ICT within an SME context is examined. Through judgement sampling, a questionnaire was distributed to gather the responses of 90 SMEs. The most important barriers that were highlighted by the results of the study are the high cost of ICT systems as well as the lack of knowledge to maintain and use ICT. The challenge is to ensure that South African SMEs continue to increase the adoption of ICT. It is envisaged that by determining the barriers they face and providing recommendations as to how they can overcome these barriers, this research will assist SMEs to become more successful, as they play a vital role in the South African economy.
\end{abstract}

Keywords: SMEs; South Africa; Developing Country; Information Communication Technology; ICT; Adoption; Barriers

\section{INTRODUCTION}

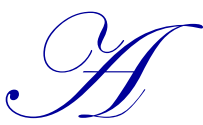

ccording to the Department of National Treasury ([sa]:13), SMEs in South Africa account for roughly $50 \%$ of the GDP and employ more than $60 \%$ of the workforce. It is evident that SMEs have a significant impact on the economy, as they contribute significantly to sociopolitical stability and unemployment challenges (Department of National Treasury [sa]:13). Therefore, it is crucial to ensure their success and long-term existence. However, according to Smit and Watkins (2012:6325), SMEs are experiencing increasing pressure due to globalization and increasing market expansion due to new technologies and innovation, which includes ICT.

The internet has changed the world by providing a platform where information is easily shared and communicated electronically from one device to another and reused for various purposes (Castro \& Misra 2013:2). Increasingly, more people have access to the internet and this has inevitably led to the internet changing society and, more specifically, the way in which businesses operate (Francis 2015). In developed countries, the internet has contributed $21 \%$ to the GDP growth and the majority of benefits received were from SMEs (Atkinson \& Stewart 2013:4). These factors have contributed towards SMEs, in developing and developed countries, adopting internet-based ICT.

Even though there have been a number of studies conducted in established countries on the adoption of ICT among SMEs, there has been limited research done in emerging countries such as South Africa. Besides, it should be noted that the established and establishing countries face different barriers specific to them. Therefore, the findings for SMEs operating in established countries cannot be generalised for SMEs operating in emerging countries (Kapurubandara \& Lawson 2006:2). However, the lessons learned from established countries can be inferred to SMEs in establishing countries. The aim of this study was to explore the common barriers to ICT usage for South African SMEs. 
In the subsequent section of the study, the literature review is discussed. This is then followed by the research objectives and research methodology that was utilised for this study. The research findings, recommendations and concluding remarks are then discussed to conclude the study.

\section{LITERATURE REVIEW}

\section{Defining SMEs in South Africa}

Maheme (2011:24) indicates that there is not a singular definition of an SME, as countries generally have their own definitions, specific to their environment. The National Small Business Amendment Act 29 of 2004, (Republic of South Africa 2004:3-4) defines a SME as

“... any separate business entity, including co-operative enterprises and non-governmental organisations, managed by one owner or more and is predominantly carried on in any sector or subsector of the economy which can be defined as a micro-, a very small, a small or a medium enterprise depending on the number of employees, total annual turnover and total gross asset value."

According to Mahembe (2011:25), SMEs in South Africa, across different industries, have an average number of employees ranging from 5 (micro) to 200 (medium), with a total annual turnover of between R0.15 million (micro) to R40.00 million (medium), and a total gross asset value of R0.10 million (micro) to R18.00 million (medium).

\section{SMEs and ICT}

The internet not only allows SMEs to contend on a more equal footing and successfully in domestic markets, but also in international markets (Kapurubandara \& Lawson 2006:1). Internet-based ICT, more specifically, has the ability to create considerable value for SMEs (Ismail, Jeffery \& Van Belle 2011:1). According to Apulu and Latham (2011:51), ICT improves organizational communication and flexibility, whereas Alam and Noor (2009:112) emphasise the capability that ICT has of improving the competiveness of businesses and, more specifically, SMEs. It has become a necessity to utilize internet-based ICT in order to conduct business, as more people are making use of it (LopazNicolas \& Soto-Acosta 2010:521). According to Lopaz-Nicolas and Soto-Acosta (2010:522), there are three general uses for ICT:

- Informative orientation, which provides one-way information directed at relevant stakeholders.

- Communicative orientation, which provides two-way information exchange with stakeholder.

- Workflow orientation, which provide prospects for automated processes.

The effective use of ICT can lower the costs of communication and increase information exchange and collaboration and develop relationships with stakeholders, which is essential in today's world, as more emphasis is placed on the flow of information in the value chain (Lopaz-Nicolas \& Soto-Acosta 2010:522). According to Tarute and Gatautis (2014:1221), businesses that adopt ICT are more inclined to perform better in the market and find it easier to differentiate themselves. The successful implementation of ICT is therefore seen as one of the essential factors that ensure the long-term growth of SMEs (Antlová, Popelínský \& Tandler 2011:4).

\section{SMEs and ICT in the South African Context}

Even though most of the emerging and established SMEs in South Africa have access to the internet, there are still a substantial number of SMEs that are not connected at all (National Youth Development Agency 2010). Figure 1 below illustrates the percentages of internet connectivity of emerging and established SMEs in South Africa. It can be seen $37 \%$ of emerging and $17 \%$ established SMEs do not have access to the internet. South Africa was ranked at 58 out of 64 countries in terms of broadband access and cost ratio, and this could be seen as the key contributing factor to the significant number of SMEs without access, as they simply cannot afford it (HumanIPO, 2013). 
However, according to Gillwald, Moyo and Stork (2012:74), the ICT sector in South Africa has experienced significant growth in competition, resulting in a slight decrease in costs. However, further recommendations were provided to ensure the growth of the ICT sector, which could result in lower costs, such as removing special taxes and duties on ICT equipment and services, supporting e-skills development and enabling the resale of ADSL (Gillwald et al. 2012:74).

Figure 1. South African SME internet connectivity*

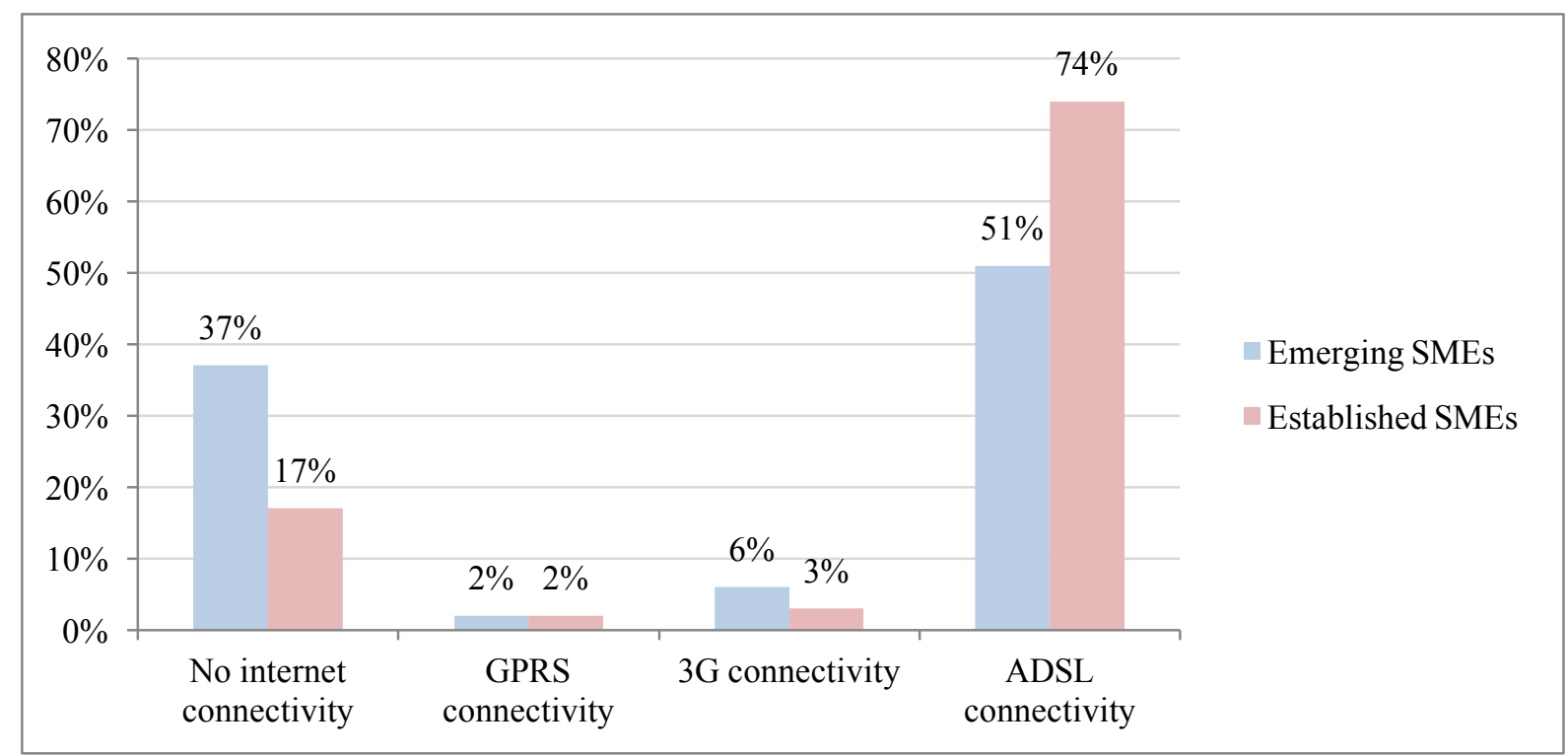

*Source adapted from: National Youth Development Agency (2010)

Furthermore, Ismail et al., (2011:4) indicate that the lack of infrastructure such as electricity and telephone lines in the rural areas of South Africa do not provide sufficient support for emerging technologies. It is evident that the South African government needs to have a hands-on approach in order to improve the broadband and cost ratio by stimulating competition in this sector in the market, which would lead to lower prices and improve the infrastructure in South Africa.

\section{SME and ICT Adoption}

As stated in the previous section, SMEs play a critical role in the economy and, with the use of ICT, SMEs are capable of ensuring their success and remaining competitive. Therefore, it is essential to scrutinise the various factors influencing ICT adoption. Alam and Noor (2009:114) suggest five independent variables affect the adoption of ICT.

- Perceived benefits. The more benefits that SMEs perceive to gain from implementing ICT, the more likely they are to adopt ICT.

- Perceived costs of adoption. The higher the costs of implementing ICT, the less likely SMEs will adopt ICT.

- ICT knowledge and skills of employees. The less knowledgeable or experienced owners or managers of SMEs, the less likely SMEs will adopt ICT.

- External pressure. The more industry stakeholders make use of ICT, the more likely it is that a SME will adopt ICT.

- Government support. The more government supports and promotes the usage of ICT, the more likely SMEs will adopt ICT. 
However, Consoli (2012:93) indicates there are five determinant factors influencing ICT adoption, namely:

- Individual factors, such as commitment from top management, personality traits and skills of employees, business culture on information system and processes in place for learning.

- Organizational factors, such as the size of the business, its culture and human capital and the employees' participation level.

- Environmental factors, such as government policies, consumers' innovation requirements and competitive pressures.

- Technological factors, which refer to the business' existing technological infrastructure.

- Economical factors, which refer to macroeconomic costs.

It is evident there are a variety of possible factors that could have an influence the adoption of ICT. According to Consoli (2012:93), SMEs are currently under utilizing the potential ICT as they experience many challenges with regard to adopting and implementing ICT. Kapurubandara and Lawson (2006:2) state that the challenges that SMEs face with regard to ICT adoption, can be summarized into two broad groups, namely internal and external barriers.

- Internal barriers refers to the controllable variables which the SMEs can control such as owners/managers' lack of awareness of the benefits of using ICT, lack of computer literacy, mistrust in the IT industry and concerns about their return on investments as well as the characteristics of an organisation such as low technology usage and the lack of funds, human resources and skills to implement ICT.

- External barriers are the uncontrollable variables that SMEs have no control over such as social, cultural, political, legal and regulatory matters (Tarute \& Gatautis 2014:1218).

Furthermore, Tan, Chong, Lin and Eze (2010:30) highlight some of the common challenges experienced by SMEs when adopting ICT. These include, among others, the following: high costs of ICT equipment and implementation, the lack of funds to employ a person to manage ICT in the SME, discrepancies between the return on investment and investment costs, absence of skilled personnel to encourage, implement and maintain ICT systems and the lack of ICT infrastructure.

\section{SME and ICT Adoption in the South African Context}

A study conducted by Ismail et al. (2011: 11) found that South African SMEs do perceive ICT adoption as beneficial and value adding; however, they experience many barriers affecting the adoption and value adding aspects. Another study conducted by Gono, Hariandranath and Özlan (2014:16) found that SMEs in the manufacturing and logistics industry needed to contract external expertise due to the fact a vast number of the respondents lacked the necessary ICT knowledge. These findings indicate that the workforce of South African SMEs lack ICT skills (Gono et al. 2014:16). Furthermore, it was found that the relationships that SMEs had with their supply chain members required them to remain current with new technological developments (Gono et al. 2014:16). Correspondingly, another study identified stakeholders (customers, suppliers and competitors) as the main pressures to adopt ICT for small hotel establishments (Mpofu, Milne \& Watkins-Mathys nd:18). In addition, this study further emphasized the significance of an owner or manager's knowledge and support of ICT (Mpofu et al. [sa]:18).

\section{RESEARCH OBJECTIVES AND RESEARCH METHODOLOGY}

The main purpose of this study was to explore the common barriers of ICT usage for SMEs in South Africa. A quantitative approach was followed to explore the barriers of ICT adoption for South African SMEs. Primary data was collected from South African SMEs in order to sufficiently address this problem. To measure the ICT adoption barriers, a quantitative survey questionnaire with five point Likert-type scales was used. The scale ranging from strongly disagree (1) to strongly agree (5). To determine the importance of the barriers, the data was quantified and analyzed through frequency counts. Cluster analysis was then utilized in order to determine if there are distinct patterns among the respondents regarding how important they rated the various factors as barriers to SMEs when they adopt internet-based ICT to communicate and/or conduct business. 
The questionnaire was administered to small business owners operating in the provinces of Gauteng and KwaZulu Natal that have registered their small businesses with an official state institution for SMEs. The combined contribution of these provinces to the national GDP is 50\% (Gauteng 33.9\%; KwaZulu Natal 16.1\%) and can therefore be regarded as representative of SMEs in South Africa. (Gauteng Online 2015).

The sampling methodology made use of non-probability, purposive sampling, which allowed the researchers to gather data efficiently. Adequate numbers of questionnaires were disseminated to achieve a confidence level of $95 \%$ and an error margin of $10 \%$ at $50 \%$ response distribution. A total of 90 usable responses were received, which is an error margin of $10.05 \%$ (Raosoft 2016). Due to the number of usable responses, the results can only provide a general indication of the barriers to adopt ICT adoption among SMEs in South Africa.

\section{Demographic Profile}

Table 1 below summarizes the demographic profile of the respondent group. More than half (56.9\%) of SME owners were older than 40 years of age. The respondent group was dominated by female respondents (58.6\%). Almost half $(46.1 \%)$ of the respondents own the business and about a third (34.2\%) were the owner and managers, which implies that the owner is directly involved in the day-to-day running of the SME. A large proportion (60.8\%) of the respondents' businesses has existed for less than five years. The largest proportion (41.8\%) of the respondents reported an annual turnover of less than R100 000.

Table 1. Demographic profile

\begin{tabular}{|c|c|c|}
\hline & & \% of Total \\
\hline \multirow{2}{*}{ Gender } & Female & 58.6 \\
\hline & Male & 41.4 \\
\hline \multirow{5}{*}{ Age } & $18-24$ & 8.7 \\
\hline & $25-29$ & 17.2 \\
\hline & $30-34$ & 6.9 \\
\hline & $35-39$ & 10.3 \\
\hline & Older than 40 & 56.9 \\
\hline \multirow{3}{*}{ Position in organization } & Owner & 46.1 \\
\hline & Manager & 19.7 \\
\hline & Both & 34.2 \\
\hline \multirow{4}{*}{ How long has the business been running for? } & Less than 5 years & 60.8 \\
\hline & $6-10$ years & 25.7 \\
\hline & $11-25$ years & 9.5 \\
\hline & Over 25 years & 4.1 \\
\hline \multirow{5}{*}{ Annual turnover } & $<\mathrm{R} 100000$ & 41.8 \\
\hline & $\mathrm{R} 100000-\mathrm{R} 200000$ & 16.4 \\
\hline & R200000 - R500000 & 11.9 \\
\hline & $\mathrm{R} 500000-\mathrm{R} 1000000$ & 16.4 \\
\hline & $>\mathrm{R} 1000000$ & 13.4 \\
\hline
\end{tabular}

\section{RESEARCH FINDINGS}

The different types of ICTs commonly used by South African SMEs, the internet-based ICT functions that SMEs use and the common barriers to ICT usage are discussed in the section that follows.

\section{The Different Types of ICTS Commonly Used By South African SME’s}

Two questions were included in the questionnaire, asking respondents to indicate which of the ICT devices and internet-based ICT functions they made use of. They could indicate any other devices or functions that were not included in the list. The answers to these two questions were used to determine the extent to which SMEs are using ICT devices and internet-based ICT functions. 


\section{ICT Devices}

Cellphones and computers or laptops are the ICT devices mostly used by SMEs, with $90.9 \%$ of the respondents using cellphones and $79.6 \%$ of them using computers or laptops. Only $27.3 \%$ of the respondents use tablets (figure 2 ).

Figure 2. ICT devices in use

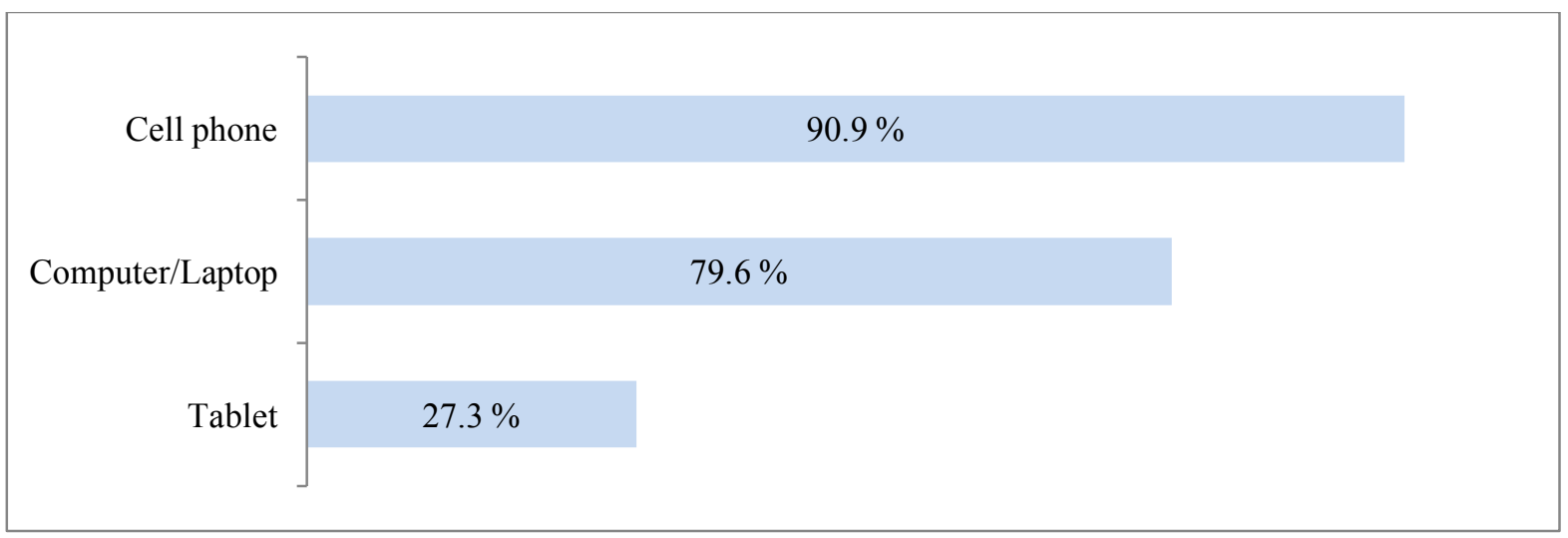

\section{Internet-Based ICT Functions}

E-mail and websites were the most used internet-based ICT functions used by SMEs, with $92.0 \%$ of the respondents indicating they use e-mail and $62.1 \%$ of respondents indicating they use a website. Online selling is conducted by $25.3 \%$ of the respondents. The rest of the internet-based ICT functions like buying online, file sharing and SMS services are used by less than $20.0 \%$ of the respondents, with $9.2 \%$ of them making use of SMS services (figure 3 ).

Figure 3. Internet-based ICT functions in use

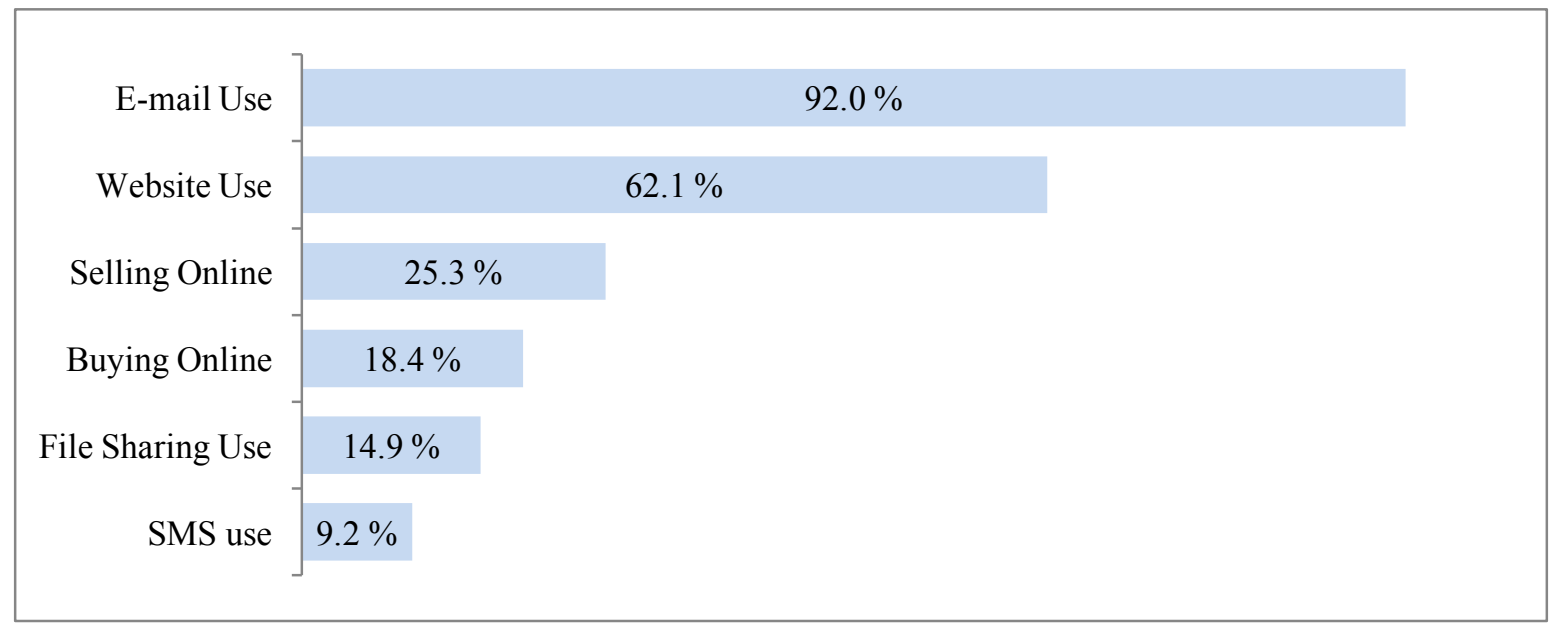

\section{Common Barriers to ICT Usage}

The participants were asked to indicate the extent to which they agreed or disagreed with statements describing common barriers that SMEs faced when adopting ICT to conduct business and/or communicate with stakeholders. Higher values mean higher levels of agreement. The agreement levels for each of the barrier factors are indicated below (table 2). 
Table 2. Frequency table of barriers of ICT use

\begin{tabular}{|c|c|c|c|c|c|c|c|}
\hline & & $\begin{array}{l}\text { Strongly } \\
\text { Disagree }\end{array}$ & Disagree & $\begin{array}{l}\text { Neither } \\
\text { disagree } \\
\text { or agree }\end{array}$ & Agree & $\begin{array}{l}\text { Strongly } \\
\text { Agree }\end{array}$ & Mean \\
\hline \multirow{2}{*}{$\begin{array}{l}\text { Not many customers and } \\
\text { suppliers have access to } \\
\text { internet }\end{array}$} & Row N \% & $16.9 \%$ & $29.2 \%$ & $5.6 \%$ & $42.7 \%$ & $5.6 \%$ & 2.91 \\
\hline & Count & 15 & 26 & 5 & 38 & 5 & \\
\hline \multirow{2}{*}{$\begin{array}{l}\text { Lack of knowledge and } \\
\text { understanding of ICT }\end{array}$} & Row N \% & $12.5 \%$ & $25.0 \%$ & $9.1 \%$ & $47.7 \%$ & $5.7 \%$ & 3.09 \\
\hline & Count & 11 & 22 & 8 & 42 & 5 & \\
\hline \multirow{2}{*}{$\begin{array}{l}\text { Lack of knowledge to set } \\
\text { up the ICT systems }\end{array}$} & Row N \% & $11.4 \%$ & $22.7 \%$ & $10.2 \%$ & $46.6 \%$ & $9.1 \%$ & 3.19 \\
\hline & Count & 10 & 20 & 9 & 41 & 8 & \\
\hline \multirow{2}{*}{$\begin{array}{l}\text { Lack of skilled workers } \\
\text { that can handle or } \\
\text { maintain ICT systems }\end{array}$} & Row N \% & $8.0 \%$ & $19.5 \%$ & $14.9 \%$ & $44.8 \%$ & $12.6 \%$ & 3.34 \\
\hline & Count & 7 & 17 & 13 & 39 & 11 & \\
\hline \multirow{2}{*}{$\begin{array}{l}\text { Lack of financial } \\
\text { resources and high costs } \\
\text { of ICT systems }\end{array}$} & Row N \% & $8.0 \%$ & $20.7 \%$ & $10.3 \%$ & $48.3 \%$ & $12.6 \%$ & 3.37 \\
\hline & Count & 7 & 18 & 9 & 42 & 11 & \\
\hline \multirow{2}{*}{$\begin{array}{l}\text { Not widely used in our } \\
\text { current business operations }\end{array}$} & Row N \% & $16.1 \%$ & $29.9 \%$ & $17.2 \%$ & $27.6 \%$ & $9.2 \%$ & 2.84 \\
\hline & Count & 14 & 26 & 15 & 24 & 8 & \\
\hline \multirow{2}{*}{$\begin{array}{l}\text { ICT has too many risks } \\
\text { involved }\end{array}$} & Row N \% & $16.1 \%$ & $33.3 \%$ & $12.6 \%$ & $31.0 \%$ & $6.9 \%$ & 2.79 \\
\hline & Count & 14 & 29 & 11 & 27 & 6 & \\
\hline
\end{tabular}

The barriers to using ICT - to communicate and/or conduct business - that were rated the highest are the lack of financial resources and high costs of ICT systems (mean $=3.37)$. This is followed by the lack of skilled workers who can handle or maintain ICT systems (mean $=3.34$ ) and the lack of knowledge to set up the ICT systems $($ mean $=3.19)$. Other barriers include the lack of knowledge and understanding of ICT (mean = 3.09); that not many customers and suppliers have access to internet (mean $=2.91$ ); that it is not widely used in their current business operations (mean $=$ 2.84 ) and that ICT has too many risks involved (mean $=2.79)$.

In order to determine the extent to which a respondent agrees with the statements, the mean values were calculated. On the scale ranging from 1 to 5 , four statements had mean values higher than the middle value (3) which indicates only those four statements described barriers to the respondents. The other three statements display a mean lower than the middle value of the scale; this means they tend more toward disagreeing with the statements being a barrier to ICT use. Furthermore, respondents did not differ much in the rating of the statements as the standard deviations are relatively low (table 3).

Table 3. Mean values of agreement for the barriers to ICT usage

\begin{tabular}{|c|c|c|c|}
\hline Barriers to ICT usage & $\mathbf{N}$ & Mean & $\begin{array}{c}\text { Std. } \\
\text { Deviation }\end{array}$ \\
\hline Not many customers and suppliers have access to internet & 89 & 2.91 & 1.276 \\
\hline Lack of knowledge and understanding of ICT & 88 & 3.09 & 1.210 \\
\hline Lack of knowledge to set up the ICT systems & 88 & 3.19 & 1.221 \\
\hline Lack of skilled workers that can handle or maintain ICT systems & 87 & 3.34 & 1.170 \\
\hline Lack of financial resources and high costs of ICT systems & 87 & 3.37 & 1.182 \\
\hline Not widely used in our current business operations & 87 & 2.84 & 1.256 \\
\hline ICT has too many risks involved & 87 & 2.79 & 1.240 \\
\hline
\end{tabular}

\section{Reliability Analysis}

An item analysis was conducted to establish whether the seven questions pertaining to the theme "Barriers of ICT" are related. An item (or reliability) analysis is a statistical technique that allows researchers to determine the internal consistency of the items that constitute the theme. An initial overall Cronbach's alpha value of 0.915 was recorded for the seven questions (table 4). The seven questions are therefore related to the theme "Barriers of ICT." 
Table 4. Reliability statistics

\begin{tabular}{c|cc}
\hline Cronbach's alpha & Cronbach's alpha based on standardised items & N of items \\
\hline 0.915 & 0.915 & 7 \\
\hline
\end{tabular}

\section{Cluster Analysis}

To establish whether there are distinct patterns among the respondents regarding how important they rated the various factors as barriers to SMEs when they adopt ICT to communication and/or conduct business, the seven items were subjected to a 2-step cluster analysis.

Two different groups were distinguished, indicating that the respondents do have different opinions regarding how important they rated the various factors as barriers. The one group consisted of 29 respondents and the second one of 55 respondents. The cluster-centre values of the separate groups are depicted in figure 4 .

Respondents from cluster 1 did not consider the 7 factors as very important barriers to SMEs. The mean rating of the seven factors by respondents in cluster 1 was 1.93 , which is below the average of 3 . Cluster 1 can be described as the "Not Agree" group; those who disagree that the factors are a barrier to ICT use. Respondents in cluster 2 agreed more towards the factors being a barrier to SMEs and their average rating was 3.70. Cluster 2 can be described as the "Agree" group.

Figure 4. Central values for the barrier clusters

\begin{tabular}{|c|c|c|c|c|c|c|c|}
\hline $\begin{array}{l}4.50 \\
4.00 \\
3.50 \\
3.00 \\
2.50 \\
2.00 \\
1.50 \\
1.00 \\
0.50 \\
0.00\end{array}$ & 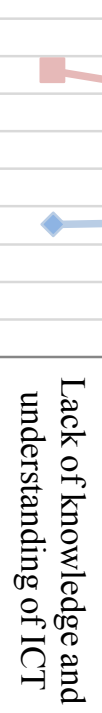 & 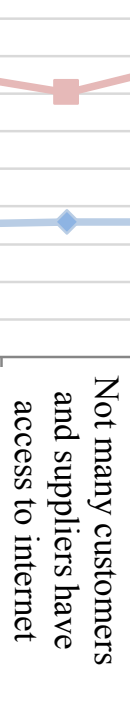 & 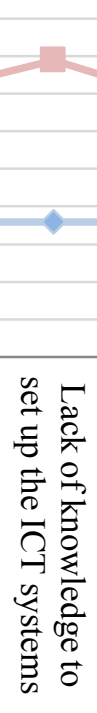 & 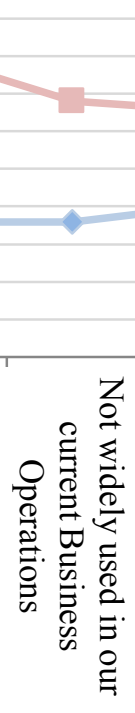 & 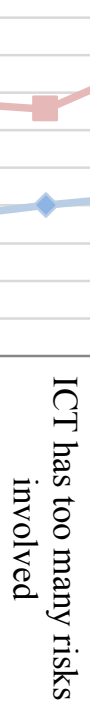 & 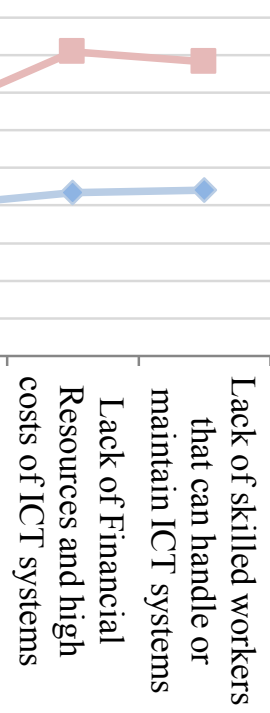 & $\begin{array}{l}\text { Cluster 1 - } \\
\text { Not Agree } \\
\text { Cluster 2 - } \\
\text { Agree }\end{array}$ \\
\hline
\end{tabular}

To understand why there is such a difference between the two clusters in their perception of the barriers to SMEs, the use of ICT devices and internet-based ICT Functions by the different cluster groups were investigated. The percentages of respondents per cluster who use the devices/functions are depicted in figure 5.

The chi-square test was used to test for significant relationships between the cluster group and the percentage of respondents using ICT devices/functions. Significant relationships $(\mathrm{p}<0.05)$ were found for buying online and e-mail use only (table 4). The "Agree" group had a significant lower percentage (13\%) of respondents who are buying online compared to the "Not Agree" group (33.3\%). Significantly more respondents (96.3\%) of the "Agree" group were using e-mail compared to the "Not Agree" group (81.5\%). 
The characteristics of the two clusters regarding the use of ICT devices and functions do not explain much of the difference between the two cluster groups in the rating of the barriers. This could be investigated further using other demographic information.

Table 4. Percentage of respondents who use ICT devices and functions and the results from the chi-square test

\begin{tabular}{l|c|c|c|c}
\hline & Negative group (\%) & Positive group (\%) & Pearson chi square & p-value \\
\hline Cellphone use & 92.9 & 92.6 & 0.02 & 0.965 \\
\hline Tablet use & 25.0 & 28.3 & 0.066 & 0.798 \\
\hline Computer/Laptop use & 71.4 & 74.1 & 0.101 & 0.751 \\
\hline File sharing use & 14.8 & 16.7 & 0.046 & 0.831 \\
\hline Selling online & 29.6 & 22.2 & 0.531 & 0.466 \\
\hline Buying online & 33.3 & 13.0 & 4.712 & 0.03 \\
\hline Website use & 51.9 & 72.2 & 3.302 & 0.069 \\
\hline SMS use & 11.1 & 7.4 & 0.313 & 0.576 \\
\hline E-mail use & 81.5 & 96.3 & 5.004 & 0.025 \\
\hline
\end{tabular}

Figure 5. Percentage of respondents using the ICT devices/functions in each cluster group

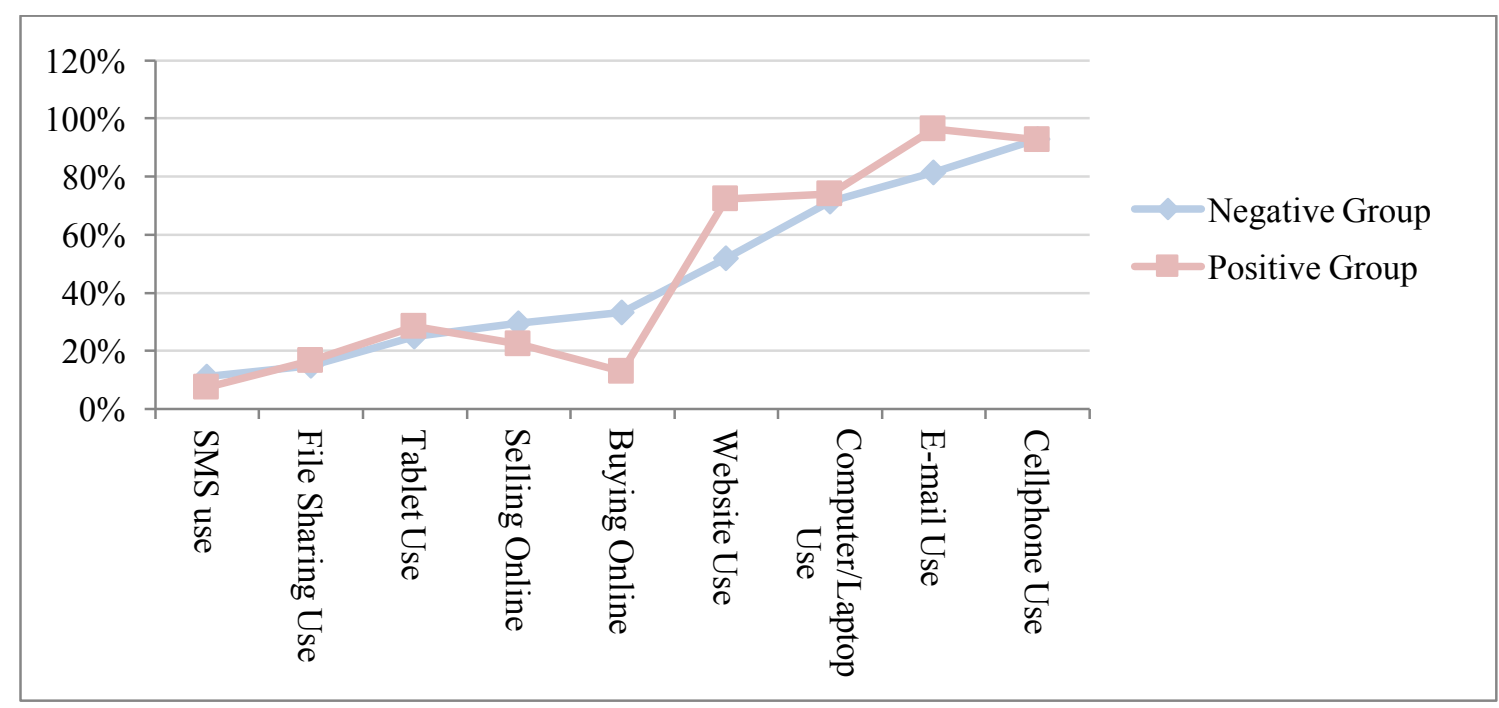

\section{CONCLUSION AND RECOMMENDATIONS}

ICT is a broad term that has been an extended term for information technology (IT), which emphasizes the role of combined communications by integrating telecommunications, computers and various systems and software which gives users the ability to access, store, communicate and manipulate information (Salampasis \& Theodoridis 2013:2). It is clear from the above the use of ICT is a core element in any business in today's world and the lack and usage thereof will affect the viability and success the business.

This study aimed to explore the common barriers of ICT usage for South African SMEs. On average, the respondents agree with four statements presented as barriers to ICT use. They are: lack of financial resources and high costs of ICT systems, the lack of skilled workers that can handle or maintain ICT systems, the lack of knowledge to set up the ICT systems and the lack of knowledge and understanding of ICT. The most important barriers that were highlighted by the results of the study are the high cost of ICT systems as well as the lack of knowledge to maintain and use it.

The findings of the study support earlier studies in terms of identified barriers, which are a lack of ICT knowledge and skills and the costs associated with ICT. 
In order for SMEs to enhance their capabilities, SMEs should be more aware of ICT devices and internet-based ICT functions. Previous studies have found that SMEs who have adopted ICT into their businesses, do reap the benefits. The main barriers identified with regard to ICT use should therefore be addressed through funding and training. Having access to ICT is adequate, however SME owners, managers and staff need training in the effective use of ICTs.

\section{AUTHOR BIOGRAPHIES}

Michael C. Cant is a Professor in the Department of Marketing and Retail Management at the University of South Africa (UNISA). He has published over 60 accredited articles in refereed journals and is the editor and author of numerous marketing textbooks. These books are widely prescribed at universities in South Africa. He has presented papers at more than 45 international conferences all over the world and is a well-respected marketing and retail scholar. He holds a D.Com. in Marketing from the University of South Africa.

Johannes A Wiid is a Professor in the Department of Marketing and Retail Management at the University of South Africa (UNISA). He holds a DCom in Marketing from the University of Johannesburg. He has published over 30 articles in refereed journals and is the editor and author of more than 5 books in marketing. These books are widely prescribed at universities in South Africa.

Yu-ting Hung is a Lecturer in the Department of Marketing and Retail Management at the University of South Africa (UNISA). She graduated from the University of Pretoria with a BCom(Hon) in Marketing Management and is currently busy with her Mcom in Business Management at the University of South Africa. She has published 4 articles in refereed journals.

\section{REFERENCES}

Alam, SS \& Noor, MKM. (2009). ICT adoption in small and medium enterprises: an empirical evidence of service sectors in Malaysia. International Journal of Business and Management 4(2):112-125.

Apulu, I \& Latham, A. 2011. Drivers for information and communication technology adoption: a case study of Nigerian small and medium sized enterprises. International Journal of Business and Management, 6(5):51-60.

Atkinson, RD \& Stewart, LA. (2013). Just the facts: the economic benefits of information and communication technology. Retrieved from: www2.itif.org/2013-tech-economy-memo.pdf (Accessed 17 August 2015).

Antlová, K, Popelínský, L \& Tandler, J. (2011). Long term growth of SME from the view of ICT competencies and web presentations. Informačni Management 4(2011):125-139.

Castro, D \& Misra, J. (2013). The internet of things. Retrieved from: http://www2.datainnovation.org/2013-internet-of-things.pdf (Accessed 21 May 2015).

Consoli, D. 2012. Literature analysis on determinant factors and the impact of ICT in SMEs. Social and Behavioral Sciences, 62(24):93-97.

Department of National Treasury. [Sa]. SMEs access to finance in South Africa. Department: National Treasury, Republic of South Africa. Retrieved from: http://www.treasury.gov.za/publications/

other/Access \%20to\%20Finance\%20in\%20South\%20Africa\%20-\%20A\%20Supply-Side\%20Regulatory\%20Re view.pdf (Accessed 21 May 2015).

Gauteng Online. (2015). The economy of Gauteng. Retrieved from: http://www.gautengonline.gov.za/Business/ Pages/TheEconomyofGauteng.aspx (Accessed 21 May 2015).

Gono, S, Harindranath, G \& Ozcan, GB. 2014. Understanding the Impact of ICT Adoption and Use in South African Manufacturing and Logistics SMEs: A Firm, Market and Regulatory (FMR) Context Perspective. Proceedings of the 2014 ISBE Conference, At Manchester, UK.

Francis, KA. (2015). How has the internet impacted businesses? Retrieved from: http://smallbusiness. chron.com/internetimpacted-businesses-321.html (Accessed 21 May 2015).

Gillwald, A, Moyo, M \& Stork, C. (2012). What is happening in ICT in South Africa. Evidence for ICT Policy Action, Policy Paper 7, 2012. Retrieved from: http://www.researchictafrica.net/

publications/Evidence_for_ICT_Policy_Action/Policy_Paper_7_Understanding_what_is_happening_in_ICT_in_Sout h_Africa.pdf (Accessed 25 February 2016).

Republic of South Africa. (2004). National small business amendment act. Government Gazette.

HumanIPO. (2013). South African Internet still too big on broadband cost and slow on speed. Retrieved from: http://www.humanipo.com/news/3200/South-African-Internet-still-too-big-on-broadband-cost-and-slow-on-spe ed/ (Accessed 9 April 2015).

Ismail, R, Jeffery, R \& Van Belle, J. (2011). Using ICT as a value adding tool in South African SMEs. Journal of African 
Research in Business \& Technology 2011(2011):1-12.

Kapurubandara, M \& Lawson, R. (2006). Barriers to adopting ICT and e-commerce with SMEs in developing countries: an exploratory study in Sri Lanka. CollECTeR, 9 December 2006, Adelaide.

Lopaz-Nicolas, C \& Soto-Acosta, P. (2010). Analysing ICT adoption and use effects on knowledge creation: an empirical investigation in SMEs. International Journal of Information Management 30(2010):521-528.

Mahembe, E. (2011). Literature review on small and medium enterprises' access to credit and support in South Africa. National Credit Regulator. Retrieved from: http://www.ncr.org.za/pdfs/Literature\%20Review\%20on\%20SME\%

20Access\%20to\%20Credit\%20in\%20South\%20Africa_Final\%20Report_NCR_Dec\%202011.pdf (Accessed 28 December 2016).

Mason, MK. (2015). Research on small business. Retrieved from: http://www.moyak.com/papers/small-business-statistics.html (Accessed 26 February 2016)

Mpofu, KC, Milne, D \& Watkins-Mathys, L. [Sa]. ICT adoption and development of e-business among SMEs in South Africa. School of Applied Computing and Advanced Technologies, Buckinghamshire New University.

OECD. [Sa]. Small businesses, job creation and growth: facts, obstacles and best practices. Retrieved from: http://www.oecd.org/cfe/smes/2090740.pdf (Accessed 25 February 2016).

National Youth Development Agency. (2010). Small and medium enterprises (SME) survey 2010: connectivity is a big issue in the emerging SME market. Retrieved from: http://www.gov.za/small-and-medium-enterprise-sme-survey-2010connectivity-big-issue-emerging-sme-market (Accessed 8 April 2014).

Raosoft. (2016). Sample Calculator. Retrieved from: http://www.raosoft.com/samplesize .html. (Accessed 28 January 2016).

Salampasis, M \& Theodoridis, A. (2013). Information and communication technology in agricultural development preface. 6th International Conference on Information and Communication Technologies in Agriculture, Food and Environment (HAICTA2013)

Smit, Y \& Watkins, JA. (2012). A literature review of small and medium enterprises (SME) risk management practices in South Africa. African Journal of Business Management 6(21):6324-6330.

Tarute, A \& Gatautis, R. (2014). ICT impact on SMEs performance. Procedia-Social and Behaviours Sciences 110:1218-1225.

Tan, KS, Chong, SC, Lin, B \& Eze, UC. (2010). Internet-based ICT adoption among SMEs: demographic versus benefits, barriers and adoption intention. Journal of Enterprise Information Management 23(1):27-55.

TechTerms. (2010). ICT. Retrieved from: http://www.techterms.com/definition/ict (Accessed 7 April 2014). 


\section{NOTES}

